\title{
Global Warming and Climate Change Truth: A study to examine the Role of Developed/Industrialised Countries behind the Environmental Imbalance
}

\author{
Dr. Priyanka Sharma \\ 303 Neelkanthvarni Apt., New Sama Vadodara-390008 Guj. India
}

\begin{abstract}
Today we have the necessary technology, resources and capacity to address every issue on the planet. Never before in the history of mankind, have human beings been as capable as we are today. We are living in a time when we have to think of protecting and conserving all that has ventured us. For the first time we have to talk of protecting the planet, in fact it was the planet that always took care of us. It is not hard to see how western attitudes towards nature led to the current crisis. We have mastered some living things and destroyed others. We have transformed the natural world but not conquered it. Time and again we have paid dearly for abusing the web of life. In this paper an attempt has been made to examine the role of Industrialised/developed countries behind Global Warming (increase in global temperatures) and Climate Change, with the help of tables and figures. The paper would also provide suggestions and strategies to mitigate the effects of Global Warming and Climate Change.
\end{abstract}

Keywords: Carbon sink, Climate Change, Developed World, Industrial Revolution, Green-house Gases, Mitigation Strategies

\section{Introduction}

The beginning of industrial revolution in what are today called the Developed countries like the United States and Europe, the sudden increase in carbon dioxide $\left(\mathrm{Co}_{2}\right)$ concentration in the atmosphere began.

Developed nations are more to blame for Global Warming. One of the key gases is $\mathrm{Co}_{2}$. it comprises more than $75 \%$ of the gases that cause the temperature change. And unlike the other green house gases (GHGs), it can last for almost 50-200 years, accumulating in the air above and adding to the greenhouse effect. Economists have concluded that there is a direct correlation between the economic growth and emissions of GHGs, atleast if the world follows the current pattern of economic development. ${ }^{[1]}$

Global Warming is literally the warming of our planet caused by a steadily thickening blanket of gases such as $\mathrm{Co}_{2}$ and air pollutants that is building up in the atmosphere. This blanket of hot-house gases traps the sun's heat and causing the planet to warm up. In the worst case scenario, Global Warming would make large areas of the world uninhabitable and cause massive food and water shortages, sparking wide spread migration and war. ${ }^{[2]}$

The facts below would make the picture more clear-

1.1 US emits 19.3 metric tonnes of $\mathrm{Co}_{2}$ per capita, India's share is 1.4 tons. This means an average American citizen uses up 14 times the amount of carbon space as the average Indian. ${ }^{[3]}$

1.2 At present much of the $\mathrm{Co}_{2}$ emissions come from the advanced countries, USA and Canada in particular emits about 20 tonnes per head. The other advanced countries emit between 12 and 6 tonnes per head. Most developing countries including India, emit well below the safe level of 2.3 tonnes per head and China just exceeds that benchmark. ${ }^{[4]}$

1.3 For a developed nation like the US, coal-burning power plants are the largest source of $\mathrm{Co}_{2}$ pollution-they produce 2.5 billion tons every year. Automobiles, the second largest source, create nearly 1.5 billion tons of $\mathrm{Co}_{2}$ annually. Infact the US emits more $\mathrm{Co}_{2}$ than China, India and Japan combined. ${ }^{[5]}$

1.4 The average American lifestyle choices makes him produce an unsustainable 20 tonnes of GHGs annually, and this is the lifestyle everybody on the planet aspires towards. ${ }^{[6]}$

1.5 The US, with only $6 \%$ of the world's people, uses almost one-third of all the energy and raw materials consumed each year and produces one-half of all pollution. All the industrialised nations combined hold only a quarter of the world's population, but they use $85-90 \%$ of its resources. ${ }^{[7]}$

1.6 The USA alone contributes over $25 \%$ of global emissions of $\mathrm{Co}_{2}{ }^{[8]}$

1.7 Each year the United States generates about a ton of trash and garbage for every person in the country. Some of this refuse is burned, thus adding to the air pollution, but most of it is buried in various landfills and dumps, creating two problems- one is the increasing number of ravines, gullies, valleys, bays and sloughs that are being covered as the trash mounts up. Another is the increasing disposal of plastic and other synthetic materials which, unlike organic material, never decompose. ${ }^{[9]}$

1.8 Americans dump about 100 millions tires and 38 billion bottles and jars each year. ${ }^{[10]}$ 


\section{Research Methodology}

The study is based on quantitative analysis and also draws on qualitative information for better understanding of the concept of Environmental Imbalance with focus on global warming and climate change. Secondary data has been referred for the study from published materials- books, magazines, world atlases and journals. Newspapers, especially The Times of India have provided immense useful information regarding environmental problem and also in cross-checking the provided data.

\section{Main Findings of the Study}

The following data in the tables and diagrams clearly presents the role of industrialised nations in warming the earth and deteriorating the environment's delicate balance.

Since the coming of Industrial Revolution and the modernisation of many of the world's societies, the rate at which these energy resources have been consumed has risen dramatically and continued to do so. In the past three decades alone, world energy consumption has nearly tripled, and most of that energy still is provided by fossil fuels (Table 1). These resources are being depleted so rapidly that many observers predict the complete exhaustion of specific fuels within the foreseeable future. For example, some estimates claim that half of all the recoverable oil in the world will have been used up by as early as 1997 and no later than the year 2017. ${ }^{[1]}$

Table 1

World Energy Consumption by Region and Energy Source (in metric tonnes of coal equivalent)

\begin{tabular}{|c|c|c|c|c|c|c|c|c|}
\hline \multirow{3}{*}{$\begin{array}{l}\text { Region and Energy } \\
\text { Source } \\
\text { World Total } \\
\end{array}$} & \multicolumn{8}{|c|}{$\begin{array}{l}\text { Consumption and Percentage Distribution } \\
\text { (millions of metric tonnes) }\end{array}$} \\
\hline & \multicolumn{2}{|c|}{1960} & \multicolumn{2}{|c|}{1970} & \multicolumn{2}{|c|}{1980} & \multicolumn{2}{|c|}{1990} \\
\hline & 3924 & $(100.0)$ & 6440 & $(100.0)$ & 8544 & $(100.0)$ & 10412 & $(100.0)$ \\
\hline North America & 1599 & 40.7 & 2502 & 38.9 & 2796 & 32.7 & 3061 & 29.4 \\
\hline United States & 1454 & 37.1 & 2217 & 34.4 & 2594 & 27.7 & 2572 & 24.7 \\
\hline South America & 79 & 2.0 & 143 & 2.2 & 251 & 2.9 & 307 & 2.9 \\
\hline Europe & 1039 & 26.5 & 1720 & 26.7 & 2145 & 25.1 & 2153 & 20.7 \\
\hline Asia & 514 & 13.1 & 903 & 14.0 & 1579 & 18.5 & 2552 & 24.5 \\
\hline Japan & 96 & 2.4 & 333 & 5.2 & 435 & 5.1 & 519 & 5.0 \\
\hline Soviet Union (former) & 595 & 15.2 & 999 & 15.5 & 1473 & 17.2 & 1931 & 18.5 \\
\hline Oceania & 41 & 1.0 & 71 & 1.1 & 105 & 1.2 & 147 & 1.4 \\
\hline \multicolumn{9}{|l|}{ Energy Source } \\
\hline Solid fuels & 1940 & 49.4 & 2159 & 33.5 & 2632 & 30.8 & 3324 & 31.9 \\
\hline Liquid fuels & 1306 & 33.3 & 2835 & 44.0 & 3778 & 44.2 & 4038 & 28.8 \\
\hline Natural gas & 593 & 15.1 & 1292 & 20.1 & 1834 & 21.5 & 2532 & 24.3 \\
\hline Electricity & 84 & 2.1 & 154 & 2.4 & 301 & 3.5 & 518 & 5.0 \\
\hline
\end{tabular}

The nations of the world consumed a total of nearly 66 million barrels (about 2.77 billion gallons) of petroleum per day in 1990, a 40\% increase from 1970 rates (Table 2). Petroleum represents about one-third of the total current industrial energy consumption in the United States, although, since 1970, all energy-use sectors except transportation have moved away from petroleum and other fossil fuels toward increase use of electricity. However, according to U.S. Department of Energy projections, petroleum consumption will grow steadily through the year 2010, with an increasing amount of that oil coming from foreign sources. ${ }^{[12]}$

Table 2

Petroleum Consumption, World and Major Consuming Nations

\begin{tabular}{|l|c|c|c|}
\hline \multirow{2}{*}{ Country } & \multicolumn{2}{|c|}{ Petroleum Consumption(millions of barrels per day) } \\
\cline { 2 - 4 } & 1970 & 1980 & 1990 \\
\hline World Total & 46.81 & 63.07 & 65.92 \\
\hline United States & 14.70 & 17.06 & 16.99 \\
\hline USSR(former) & 5.31 & 9.00 & 8.40 \\
\hline Japan & 3.82 & 4.96 & 5.14 \\
\hline West Germany & 2.61 & 2.71 & 2.38 \\
\hline United Kingdom & 2.10 & 1.73 & 1.75 \\
\hline France & 1.94 & 2.26 & 1.81 \\
\hline Italy & 1.71 & 1.93 & 1.87 \\
\hline Canada & 1.52 & 1.87 & 1.69 \\
\hline China (PRC) & 0.62 & 1.77 & 2.28 \\
\hline
\end{tabular}

As of 1992, 364 commercial nuclear-powered reactors were in operation around the world, producing a total of nearly 1,900 billion kilowatt hours of electricity (Table 3). These numbers represents a six-fold increase in 
the number of reactors but less than a tripling in the amount of electricity generated since 1970. Nuclear energy was once hailed as the most viable solution to the world's energy needs, but rapidly rising construction and operating costs as well as mounting questions about the health and safety hazards of nuclear energy, have led to significant reversals in this once-booming area. ${ }^{[13]}$

Table 3

Commercial Nuclear Power Generation, World and Selected Countries 1992(in billions of kilowatt-hours)

\begin{tabular}{|l|c|c|}
\hline Country & Reactors & Electricity Generated \\
\hline World Total & 364 & 1868.3 \\
\hline United States & 112 & 650.0 \\
\hline France & 57 & 337.6 \\
\hline Japan & 42 & 215.8 \\
\hline Great Britain & 37 & 78.5 \\
\hline Germany & 22 & 158.8 \\
\hline Canada & 20 & 81.3 \\
\hline Sweden & 12 & 63.5 \\
\hline South Korea & 9 & 56.4 \\
\hline Spain & 9 & 55.8 \\
\hline India & 8 & 6.3 \\
\hline
\end{tabular}

Since the advent of the Modern Age and the industrialisation of the world's societies, the earth's natural ability to cleanse itself of atmospheric pollutants has been strained to the point of collapse. Each year, the United States and other developed countries pour millions of tons of toxic pollutants into the air in the course of heating, cooling and powering the economies that sustain the social well-being of their populations (Table 4). And each year, the developing nations of the world disgorge rapidly growing amounts of the same fossil fuel and chlorofluorocarbon (CFC) emissions into the atmosphere as they industrialise and modernise in an effort to improve their own population's levels of well being. Ironically, one of the net results of this attempted global upgrading of human societal life has been the global downgrading of the physical environment and, ultimately, of human societal life as well. The atmosphere that is meant to sustain us is now dirtier, unhealthier, warmer, and thinner than at any previous point in recorded history. ${ }^{[14]}$

Table 4

Air Pollutant Emissions in the United States: 1991 (by pollutant and source)

\begin{tabular}{|c|c|c|c|c|c|c|}
\hline \multirow[t]{2}{*}{ Pollutant } & \multicolumn{6}{|c|}{ Source } \\
\hline & $\begin{array}{c}\text { Total } \\
\text { Emissions }\end{array}$ & Transportation & $\begin{array}{c}\text { Fuel } \\
\text { Combustion }^{1}\end{array}$ & $\begin{array}{l}\text { Industrial } \\
\text { Process }\end{array}$ & $\begin{array}{c}\text { Solid Waste } \\
\text { Disposal }\end{array}$ & Miscellaneous \\
\hline Carbon monoxide $^{2}$ & 62.1 & 43.5 & 4.7 & 4.7 & 2.1 & 7.2 \\
\hline Sulphur oxides $^{2}$ & 20.7 & 1.0 & 16.6 & 3.2 & 0.2 & 0.1 \\
\hline $\begin{array}{l}\text { Volatile organic } \\
\text { compounds }^{2}\end{array}$ & 16.9 & 5.1 & 0.7 & 7.9 & 0.7 & 2.6 \\
\hline Particulates $^{2}$ & 7.4 & 1.6 & 1.9 & 2.6 & 0.3 & 1.0 \\
\hline Nitrogen oxides $^{2}$ & 18.8 & 7.3 & 10.6 & 0.6 & 0.1 & 0.2 \\
\hline Lead $^{3}$ & 5.0 & 1.6 & 0.5 & 2.2 & 0.7 & 0.0 \\
\hline \multicolumn{7}{|l|}{${ }^{1}$ Stationary sources } \\
\hline \multicolumn{7}{|c|}{${ }^{2}$ Millions of metric tons per year } \\
\hline${ }^{3}$ Thousands of metr & s per year & & & & & \\
\hline
\end{tabular}

The Table 5 presents the emissions of carbon dioxide (tonnes of carbon) by different countries from 18002000. The developed countries- USA, Russia, Germany tops the list with maximum carbon dioxide emissions into the atmosphere. ${ }^{[15]}$

Table 5

Carbon dioxide emissions

\begin{tabular}{|l|c|}
\hline Country & $\begin{array}{c}\text { Carbon dioxide emissions 1800- } \\
\text { 2000(tonnes of carbon) }\end{array}$ \\
\hline USA & $301,279,000,000$ \\
\hline Russia & $86,705,000,000$ \\
\hline Germany & $75,606,000,000$ \\
\hline China & $72,615,000,000$ \\
\hline UK & $68,803,000,000$ \\
\hline Japan & $36,577,000,000$ \\
\hline France & $30,997,000,000$ \\
\hline
\end{tabular}


The Table 6 shows the major culprits of GHGs emissions and Table 7 gives different sectors of GHGs emissions. The developed countries the main culprits should cut their carbon emissions at least by $80 \%$ by the year 2050 and fast growing economies like India and China by $20 \%$. And emissions in different sectors especially energy, needs special focus and cut down. ${ }^{[16]}$

Table 6

Greenhouse Gases Major Culprits

\begin{tabular}{|l|c|c|}
\hline Country & $\begin{array}{c}\mathrm{CO}_{2} \text { Emissions (Million } \\
\text { Tons) }\end{array}$ & $\begin{array}{c}\mathrm{CO}_{2} \text { Emissions per capita } \\
\text { (Tons) }\end{array}$ \\
\hline United States & 6046 & 20.6 \\
\hline China & 5007 & 3.8 \\
\hline Russia & 1524 & 10.6 \\
\hline India & 1342 & 1.2 \\
\hline Japan & 1257 & 9.9 \\
\hline Germany & 808 & 9.8 \\
\hline Canada & 639 & 20.0 \\
\hline United Kingdom & 587 & 9.8 \\
\hline Korea & 465 & 9.7 \\
\hline Italy & 450 & 7.8 \\
\hline World & 28,983 & 4.5 \\
\hline
\end{tabular}

Source-The Times of India, 29 November, 2007

Table 7

Sectors of Greenhouse Gases Emissions

\begin{tabular}{|c|c|}
\hline Sector & End use/activity \\
\hline Energy & $64.8 \%$ \\
\hline Road & 9.9 \\
\hline Air & 1.6 \\
\hline Rail, Ship and other transport & 2.3 \\
\hline Residential buildings & 9.9 \\
\hline Commercial buildings & 5.4 \\
\hline Unallocated Fuel Combustion & 3.5 \\
\hline Iron and Steel & 3.2 \\
\hline Chemicals & 4.8 \\
\hline Cement & 3.8 \\
\hline Other industry & 5 \\
\hline $\mathrm{T}$ and D Losses & 1.9 \\
\hline Coal Mining & 1.4 \\
\hline OPI/Gas Extraction, Refining and Processing & 6.3 \\
\hline Land use change & $18.2 \%$ \\
\hline Deforestation & 18.3 \\
\hline Afforestation & -1.5 \\
\hline Reforestation & -0.5 \\
\hline Harvest/Management & 2.5 \\
\hline Others & -0.6 \\
\hline Agriculture & $13.5 \%$ \\
\hline Agricultural energy used & 1.4 \\
\hline Agricultural soils & 6 \\
\hline Livestock and Manure & 5.1 \\
\hline Rice Cultivation & 1.5 \\
\hline Other agriculture & .09 \\
\hline Waste & $3.6 \%$ \\
\hline Landfills & 2 \\
\hline Waste water/other waste & 1.6 \\
\hline
\end{tabular}

Source- The Times of India, 12, May, 2007

Modern industrial society would be impossible without massive supplies of energy. Worldwide consumption of non-renewable energy resources has grown at a staggering pace. By the beginning of twentieth century, coal was the world's principal source of power and oil was just coming into use. Only three generations later, the United States gets three-fourths of its energy from petroleum. Western Europe and Japan get about two-thirds of their power from that source, and the communist countries get about two-fifths of theirs. The increasing use of non-renewable energy reserves has made possible an enormous growth in energy consumption. From 1950 to 1973, world energy consumption rose about $7 \%$ a year. In the 10 years between 1960 and 1970, consumption of the power in the United States increased by almost two-thirds. About $40 \%$ of this power goes directly to industrial production. The remainder is used for heating, lighting and transportation, as well as for running an array of home conveniences ranging from refrigerators and air-conditioners to electric tooth-brushes (Fig. 1). ${ }^{[17]}$ 


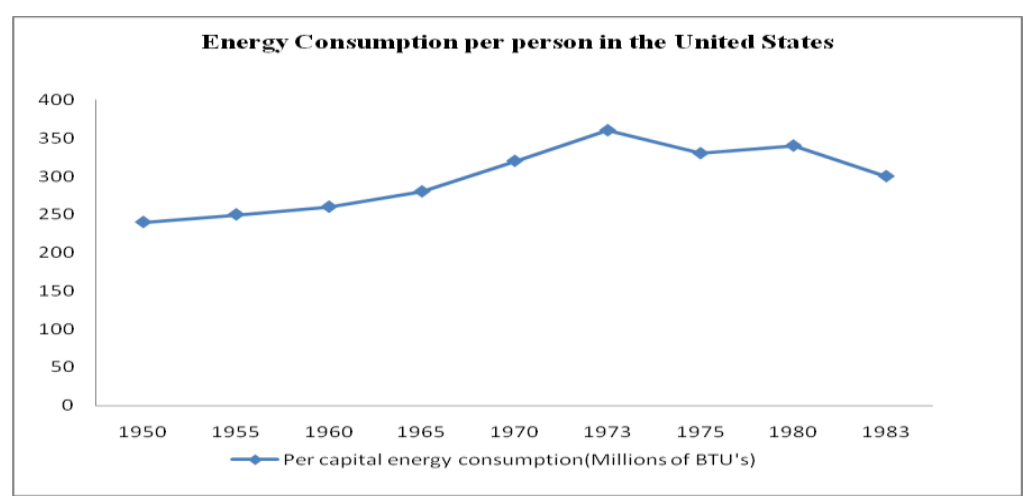

Figure 1

The capitalist nations such as United States and Canada have economic and political systems that help wealthy and powerful people exploit the poor and the weak. When these systems are applied to the environment, the natural wealth of the people as a whole is destroyed in the interest of the few. The wealthy industrialised nations are using their power to loot the poor nations of their irreplaceable natural resources, thus making the rich nations richer and the poor nations poorer. As the less developed nations are finally trying to industrialise, they find that the cheap energy and raw materials that helped the wealthy nations to develop are gone (Fig. 2) ${ }^{[18]}$

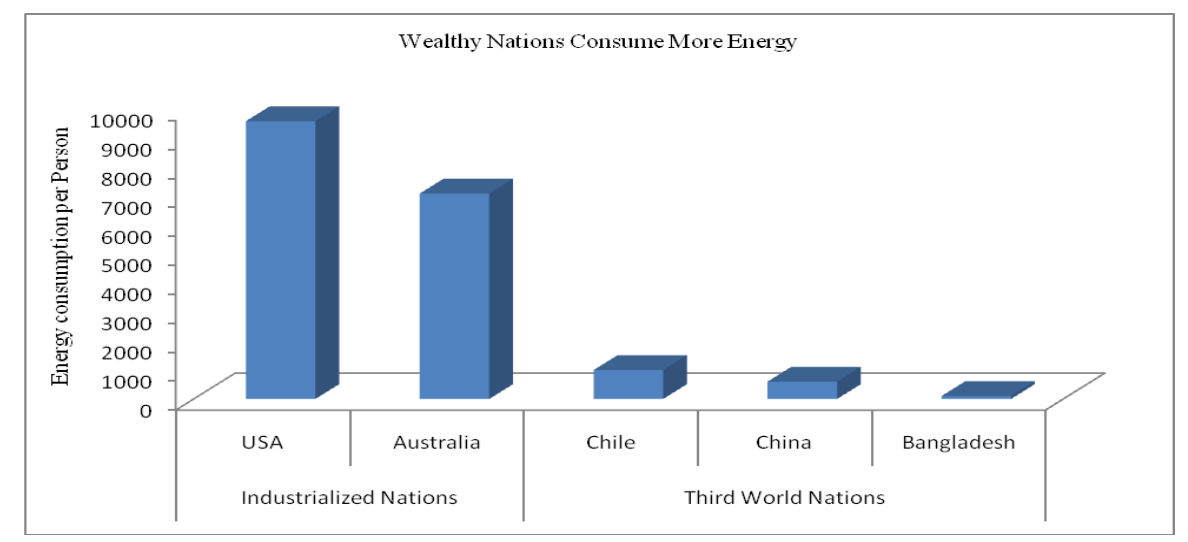

Figure 2

The Fig. 3 presents the percentage of different green-house gases present in the atmosphere, as included by IPCC. Green-house gases in the Earth's atmosphere, such as carbon dioxide, nitrous oxide, methane and others help to trap heat and stop too much of it escaping into space. But more and more green-house gases are being released into the atmosphere from human activities- burning fossil-fuels (coal and oil), cement manufacturing and gas burning; and too much heat is being trapped, thus leading to global warming. ${ }^{[19]}$ Carbon dioxide, with maximum percentage, has a green house potential of only 1 but its concentration of 350 parts per million, make it predominate ${ }^{[20]}$ Most green-house gases have both natural and anthropogenic sources. Since the industrial revolution, levels of these gases have increased due to human activities. The global atmospheric concentration of carbon dioxide increased from pre-industrial value of $280 \mathrm{ppm}$ to $379 \mathrm{ppm}$ in 2005 . The annual concentration of carbon dioxide growth rate was higher during the last ten years $(1995-2005)^{[21]}$

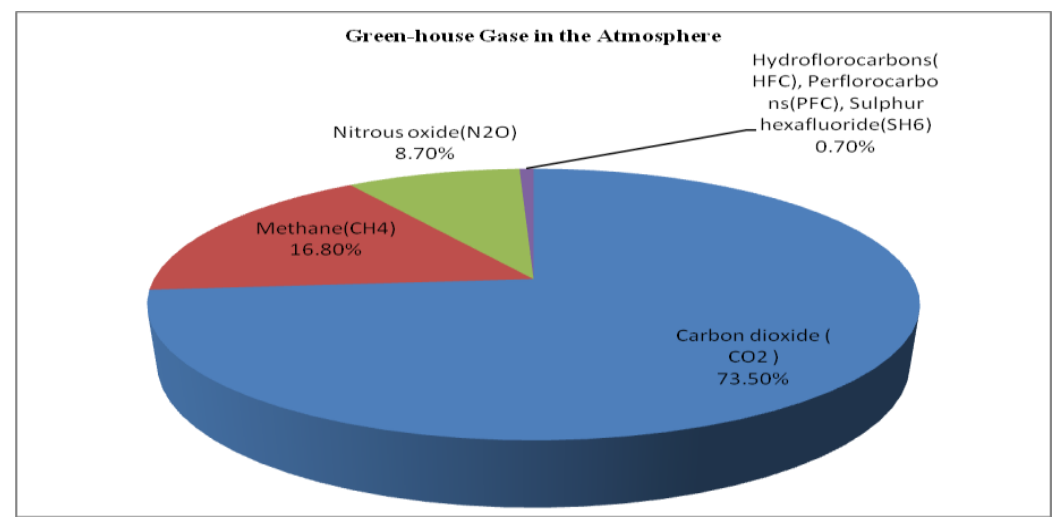

Figure 3 
The Fig. 4 presents the release of carbon dioxide in millions of tonnes (1980s) by different countries from fuel burning and deforestation. Again the share of developed countries is much more than the developing countries, with USA and USSR being the major culprits, followed by China, Brazil, Germany, Japan and other countries. The net increase in atmospheric carbon dioxide comes from fossil fuel combustion, deforestation and changing land use also contribute. ${ }^{[22]}$

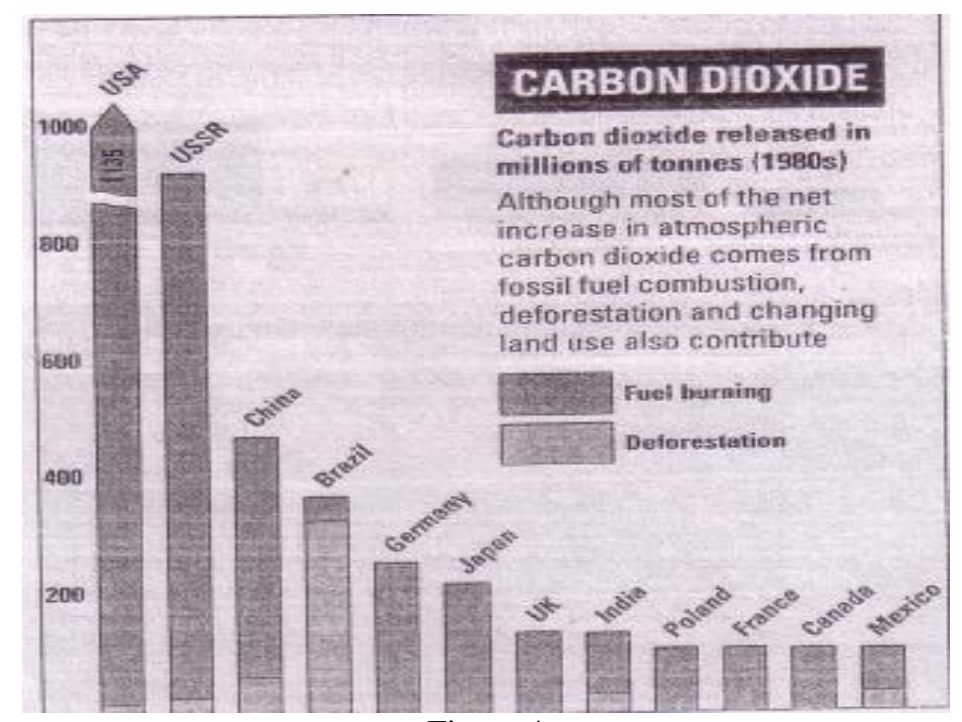

Figure 4

The Fig. 5 represents the percentage of different countries (developed and developing) contributing to atmospheric carbon dioxide concentrations. It is very clear from the figure that the developed countries are the major culprits, with 83.7 percent share in contributing to atmospheric carbon dioxide concentrations. ${ }^{[23]}$

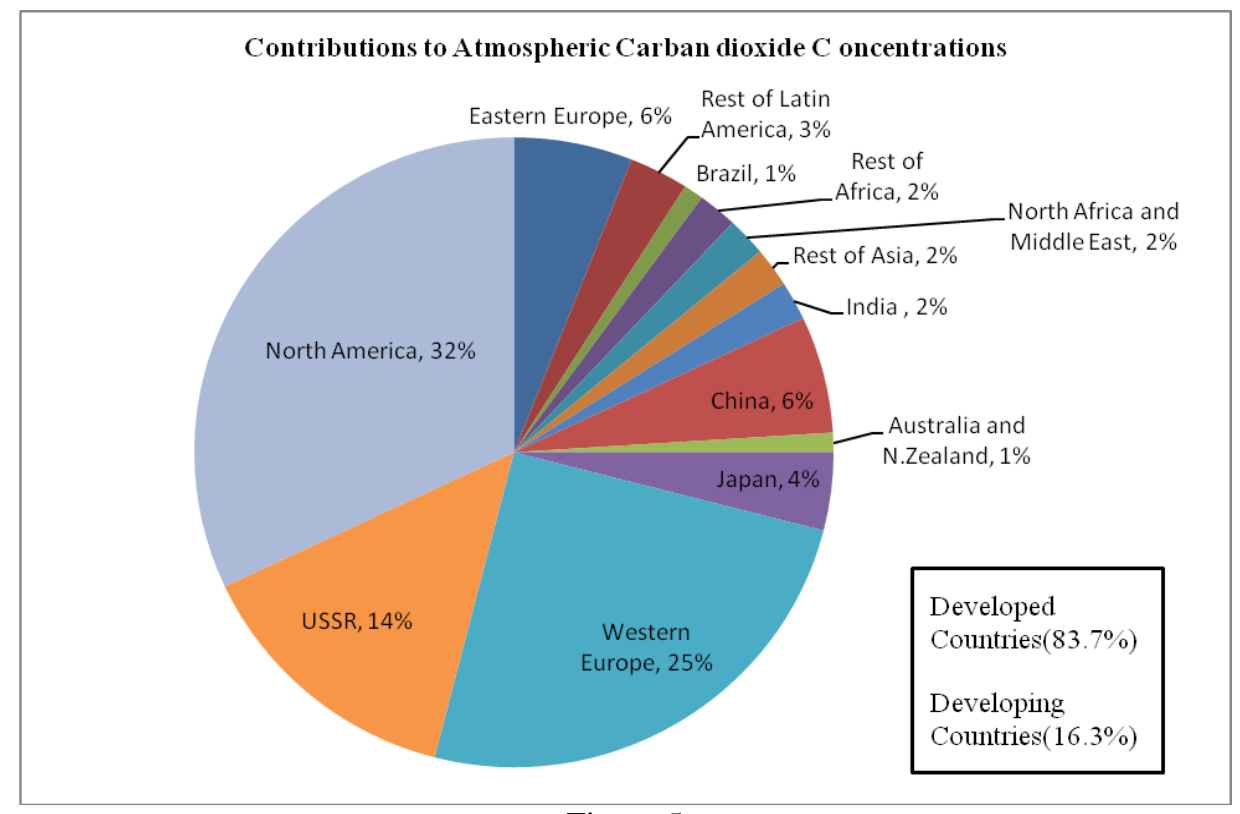

Figure 5

Since the beginning of the Industrial Revolution, human activity has pumped steadily more carbon dioxide into the atmosphere. Most was quietly absorbed by the oceans, whose immense 'sink' capacity meant that 170 years were needed for levels to increase from pre-industrial 280 parts per million to 300 (inset graph). But the vast increase in fuel-burning since 1950 (main graph) has overwhelmed even the oceanic sink. Atmospheric concentrations are now rising almost as steeply as carbon dioxide emissions themselves. The Fig. 6 shows the rise in carbon dioxide in millions of tonnes from 1950-1991, following an increasing trend from 1950 onwards. ${ }^{[24]}$ 


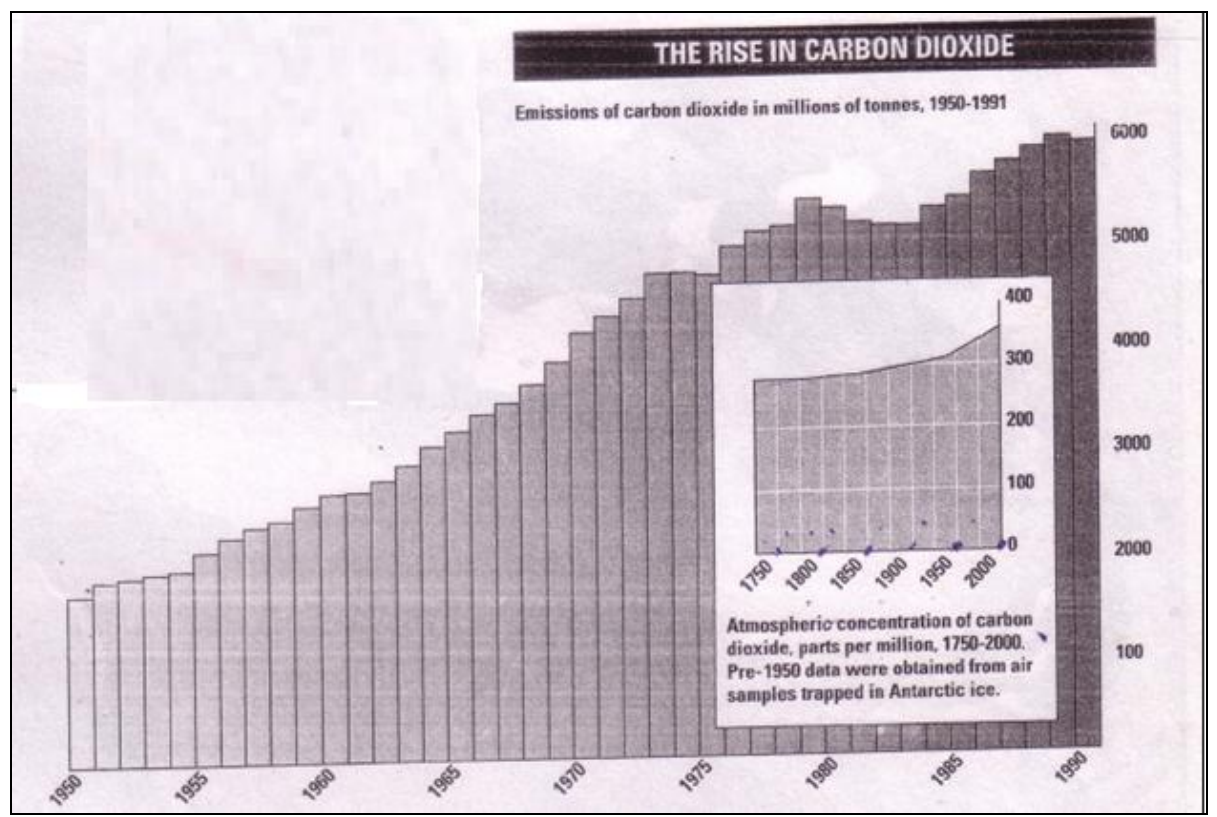

Figure 6

The Fig. 7 shows the distribution of natural disasters from1900-2005. Evidence suggests that disasters are increasing in numbers and intensity, causing significant damage to the current generation of the planet's inhabitants, particularly in Asia-Pacific. With the increase in hydro-meteorological disasters, a new community of victims called 'environmental migrants' or 'climate refuges' has come into existence with many of their issues unaddressed giving new dimension to the ongoing economic crisis. ${ }^{[25]}$

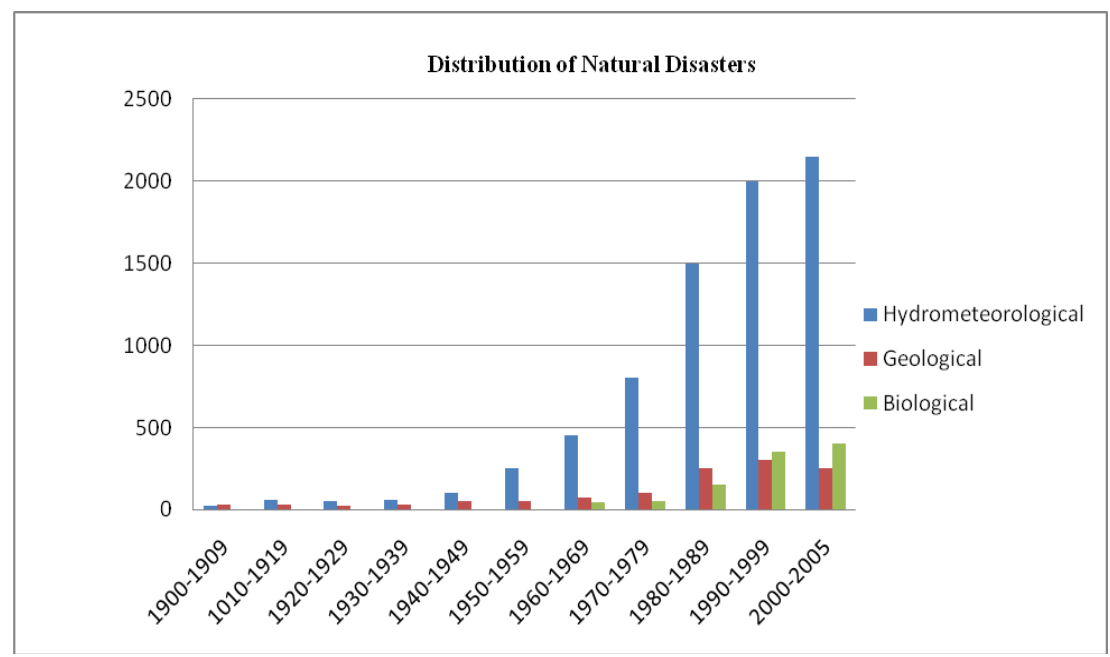

Figure 7

\section{Future Projections}

The earth's surface is warming. The temperature increase since the late 1800s may seem small, but the impact on people is likely to be profound. The impact will be even greater as temperatures continue rising, by as much as $6.4^{*} \mathrm{C}$ by $2100{ }^{[26]}$ Projected changes in the atmospheric concentrations of green-house gases and aerosols are projected to result in increase in global mean surface temperatures between 1990-2100 of 1.1 to $6.4^{*}$ $\mathrm{C}$, with land areas warming more than the oceans, and high latitudes warming more than the tropics. Globally averaged precipitations projected to increase, but with increases and decreases in particular regions, accompanied by more intense precipitation events over major regions of the world, and global mean sea-level is projected to rise by up to 0.5 meters, between $1990-2100$, even without considering a contribution from melting of Greenland ice-sheets. The incidence of extreme weather events is projected to increase- hot days, floods and droughts. ${ }^{[27]}$ 
A rise in earth's temperatures can in turn root to other alterations in the ecology, including and increasing sea level and modifying the quantity and pattern of rainfall. There modifications may boost the occurrence and concentration of severe climate events, such as floods, famines, heat waves, tornados and twisters. Other consequences may comprise of higher or lower agricultural outputs, glaciers melting, lesser summer stream flows, genus extinctions and rise in the ranges of disease vectors.

As an effect of global warming various new diseases have emerged lately. These diseases are occurring frequently, due to the increase in earth's average temperature. Since the bacteria can survive better in elevated temperatures and even multiplies faster when the conditions are favourable. The global warming is extending the distribution of the mosquitoes due to the increase in humidity levels and their frequent growth in warmer atmosphere. Various diseases due to ebola, hanta and machupo virus are expected due to warmer climates (Fig. $8,9$ and 10$) \cdot{ }^{[28]}$

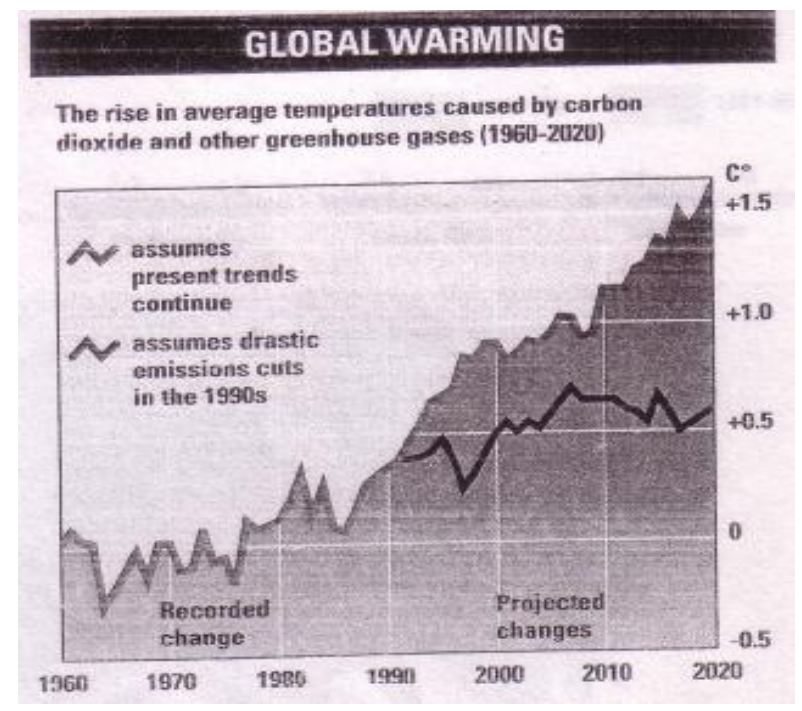

Figure 8
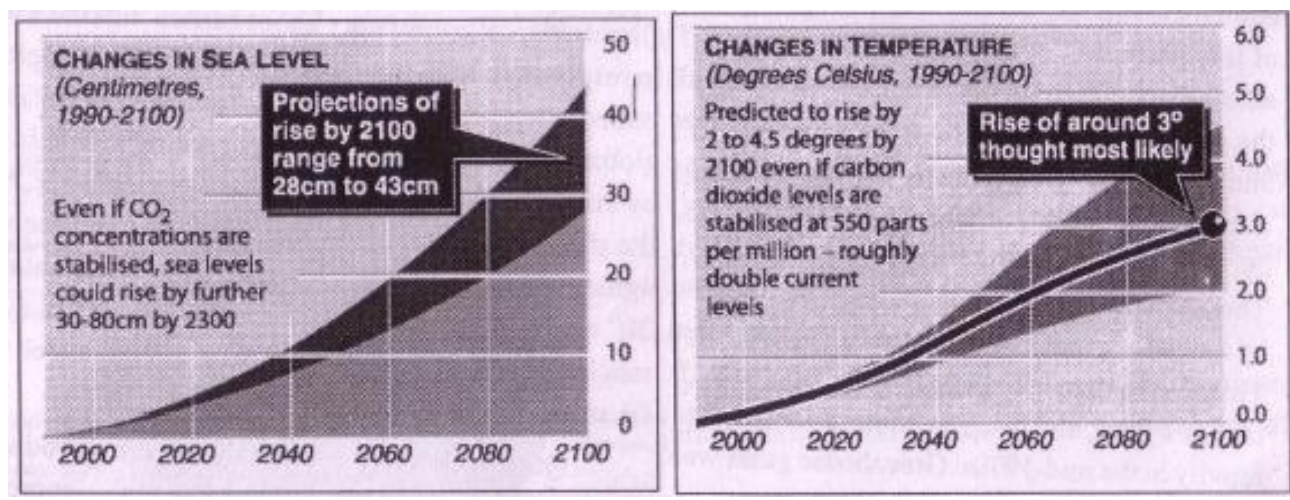

Figure 9 and 10

\section{Mitigation And Adaptation To Climate Change}

Possibly, there can be two approaches: one is mitigation and second is adaptation to climate change. ${ }^{[29]}$ The IPCC defines mitigation as activities that reduce green-house gas emissions, or enhance the capacity of carbon sinks to absorb GHGs from the atmosphere.

Many countries, both developed and developing, are aiming to use cleaner, less polluting technologies. Use of these technologies aids mitigation and could result in substantial reduction in $\mathrm{Co}_{2}$ emissions. Policies include targets for emissions reductions, increased use of renewable energy and increased energy efficiency. Studies indicate substantial potential for future reductions in emissions. Since even in the most optimistic scenario, fossil fuels are going to be used for years to come, mitigation may also involve carbon capture and storage, a process that traps $\mathrm{CO} 2 \mathrm{Co}_{2}$ produced by factories and gas or coal power stations and then stores it, usually underground. ${ }^{[30]}$ 
Adaptation is making changes in lives and lifestyles to beat back the assault. To survive people are striking back- adapting, altering and improvising to face the challenges of climate change. Besides, migration of coastal population, increasing public transport and forestry are the main adaptations that India can opt for. ${ }^{[31]}$

5.1 Increase forested area to $33 \%$ of the total geographical area. Deforestation is responsible between $20-25 \%$ of global green-house gases emissions. I $t$ is warned that a third of the State's bio-diversity would vanish or would be close to extinction by 2030. There is a urgent need for action plan in protecting natural forests at the state and national levels to slow down global warming and to check extinction of forest species. In addition, tree-planting should be on top priority under various schemes viz., afforestation, agro-forestry, social-forestry and farm level plantation as a part of carbon sequestration. Adoption of forest conservation, reforesration, afforestation and sustainable forest management practices can contribute to conservation of bio-diversity, water-shed protection, rural employment generation, increased incomes to forest dwellers and carbon sink enhancement.

5.2 Increase carbon fixation in the soil by growing deep-rooted crops so as to decrease carbon foot-print: deeprooted crops helps in addition of more biomass in the soil and after decomposition of that root biomass may fix the significant quantity of carbon content in the soil and increase the productivity of soil in a eco-friendly system.

5.3 Use water judiciously- technologies in rain-water harvesting, water conservation, judicious use of water and in-situ soil moisture conservation should be popularised to mitigate the effects of drought during summer when prolonged dry spell occurs if pre-monsoon showers fail.

5.4 Use less fossil fuels as per need and contribute in reduction of carbon dioxide and other gases responsible for global warming. Efficient, fast and reliable public transport systems such as metro-railways can reduce urban congestion, local pollution and green-house gas emissions.

5.5 Use more solar/wind sources of energy: adoption of cost-effective energy-efficient technologies in electricity generation, transmission distribution, and end-use can reduce costs and local pollution in addition to reduction of green-house gas emissions.

5.6 Educate farmers on the dangers of climate change: adoption of participatory approach to forest management, rural energy, irrigation water management and rural development in general can promote sustained development activities and ensure long term green-house gas emission reduction or carbon sink enhancement. Improved understanding of the exposure, sensitivity, adaptability and vulnerability of physical, ecological and social systems to climate change, at regional and local level. ${ }^{[32]}$

5.7 Measures suggested by Intergovernmental Panel on Climate Change (IPCC)-

- Implementing cost effective fuel.

- Implementing energy efficiency measures and providing global platforms for energy efficiency improvement programmes.

- Improving existing policies and practice to limit emissions.

- Measures to raise and expand carbon sinks that trap carbon dioxide such as forest management and proper land management etc.

- Pre-planning for the adaptation to climate change consequences in the worst case scenario.

- Revising and implementing current-energy efficiency standards globally to check emissions.

- Promoting environmental education and awareness training in schools and colleges for climate change and associated environmental issues. ${ }^{[33]}$

\section{Conclusion}

Western people look at nature as something to be conquered and exploited. They show little of reverence and respect for nature. The world would be more peaceful and more secure, if the people of industrialised nation learned to accept a more leisurely life-style and a lower standard of living while encouraging economic growth in the third world. Besides, the argument that economic growth is necessary to eliminate poverty and create more egalitarian society is also misleading. Despite decades of rapid economic growth, the industrialised nations continue to show enormous inequalities of wealth and power.

Scientific studies say that if all the insects disappear from the planet tomorrow, then life here will last only another 25 years. No life form will be able to survive, including bacterial life, everything will die, if insects go away. But if human beings disappear tomorrow, in 25 years time, earth will be flourishing. Though everything we do is not bio-degradable, fortunately our bodies are bio-degradable and so the world can do fine. 
More and more people are coming to realise that the magnificent technological advances that have made life so much more comfortable have a dark side as well. As we have seen industrial technology is polluting the environment, agricultural technology has brought havoc to the biosphere, and military technology has for the first time in history given humanity the means to destroy itself. And even if we do not destroy ourselves directly with nuclear bombs, we may do it indirectly by disrupting ecosystems, food-chains and the whole lifesupporting system. The modern world is just beginning to discover, what a heavy price future generations will have to pay for our thoughtless use of exploitative technology.

\section{Acknowledgement}

Corresponding author wishes to acknowledge her grandfather, Dr. G.S. Bharadwaj (Retd. Agriculture Scientist) for his inspirational attitude and valuable guidance. Her husband Mr. Pramod Sharma, for his love and support throughout, and all family members, friends and well-wishers.

\section{References}

[1]. India stresses on Kyoto standards, The Times of India, Delhi, 12 May 2007

[2]. Global Warming and Climate Change, The Times of India, Delhi, 8 August 2007

[3]. The Times of India,29 November 2011

[4]. The Spence Solution, The Times of India 24 September 2009

[5]. Global Warming and Climate Change, The Times of India, Delhi, 8 August 2007

[6]. The Spence Solution, The Times of India 24 September 2009

[7]. James Coleman ,Donald Cressey, The Environment, Social Problems, (Harper and Row Publishers, New York, 1987) 534

[8]. The Times of India, Delhi, 5 February 2007

[9]. Coleman ,Donald Cressey, The Environment, Social Problems, (Harper and Row Publishers, New York, 1987$) 529$

[10]. James Coleman ,Donald Cressey, The Environment, Social Problems, (Harper and Row Publishers, New York, 1987) 529

[11]. Soroka Michael, Bryjak George, Environmental Problems: Trashing the Planet, Social Problems: A World at Risk, (Allyn and Bacon, Boston, USA, 1995) 106-107

[12]. Soroka Michael, Bryjak George, Environmental Problems: Trashing the Planet, Social Problems: A World at Risk, (Allyn and Bacon, Boston, USA, 1995) 107-108

[13]. Soroka Michael, Bryjak George, Environmental Problems: Trashing the Planet, Social Problems: A World at Risk, (Allyn and Bacon, Boston, USA, 1995) 109-110

[14]. Soroka Michael, Bryjak George, Environmental Problems: Trashing the Planet, Social Problems: A World at Risk, (Allyn and Bacon, Boston, USA, 1995) 115-116

[15]. Russell Ash, Whitakers world of facts, (Penguin Books India, New Delhi, 2007)

[16]. The Times of India,29 November 2011

[17]. James Coleman ,Donald Cressey, The Environment, Social Problems, (Harper and Row Publishers, New York, 1987) 535

[18]. James Coleman ,Donald Cressey, The Environment, Social Problems, (Harper and Row Publishers, New York, 1987) 547-548

[19]. Russell Ash, Whitakers world of facts, (Penguin Books India, New Delhi, 2007)

[20]. Philip's Atlas of the World, Second Edition, (George Philip Limited, 59 Grosvenor Street, London W1X9DA, 1992) 46

[21]. Ali Seid Mohammed, Kon Daniel Awan, Global climate change and its impact on livestock production, Climate Change and Agriculture- Emerging Scenarios and Adaptation Strategies, , (Biotech Books New Delhi, 2012)125

[22]. Philip's Atlas of the World, Second Edition, (George Philip Limited, 59 Grosvenor Street, London W1X9DA, 1992) 46

[23]. Agrawal and Narayan, 1992

[24]. Philip's Atlas of the World, Second Edition, (George Philip Limited, 59 Grosvenor Street, London W1X9DA, 1992) 46

[25]. Jiya A.Shahani, Dr.Vinod Sen, Environmental Imbalance and Consumerism, Environmental Imbalance and Global Warming,,(Gaurav Prakashan Rewa, M.P., 2010),161

[26]. Ali Seid Mohammed, Kon Daniel Awan, Global climate change and its impact on livestock production, Climate Change and Agriculture- Emerging Scenarios and Adaptation Strategies, , (Biotech Books New Delhi, 2012)124

[27]. Ali Seid Mohammed, Kon Daniel Awan, Global climate change and its impact on livestock production, Climate Change and Agriculture- Emerging Scenarios and Adaptation Strategies, , (Biotech Books New Delhi, 2012)126

[28]. Lal Singh, Parmeet Singh, B.A.Khanday, Subhash Chand, Factors for climate change- Efforts to overcome global warming impact on agricultural production system and livelihood, Climate Change and Agriculture- Emerging Scenarios and Adaptation Strategies, , (Biotech Books New Delhi, 2012)79-80

[29]. Dr. R.P.Saharia, Dr. D.V.Singh, Climate Change: It's Impact on India, Climate Change-Problems and Solutions of Increasing Temperarure, (ShreeRam Prakashan Gwalior, M.P., 2012) 188

[30]. Dr. S.N.Kalia, S.N.Kudnar, Global Warming and Environmental Imbalance, Climate Change-Problems and Solutions of Increasing Temperarure, (ShreeRam Prakashan Gwalior, M.P., 2012)173

[31]. Fending off the Climate Attack, The Times of India, 27 May 2012

[32]. Lal Singh, Parmeet Singh, B.A.Khanday, Subhash Chand, Factors for climate change- Efforts to overcome global warming impact on agricultural production system and livelihood, Climate Change and Agriculture- Emerging Scenarios and Adaptation Strategies, , (Biotech Books New Delhi, 2012) 89-91

[33]. Pooja Gupta, Change in Environment, it's effect and solution, Climate Change-Problems and Solutions of Increasing Temperarure, (ShreeRam Prakashan Gwalior, M.P., 2012) 72 
Global Warming and Climate Change truth: A study to examine the role of Developed.....

The World feeling the heat of Global Warming

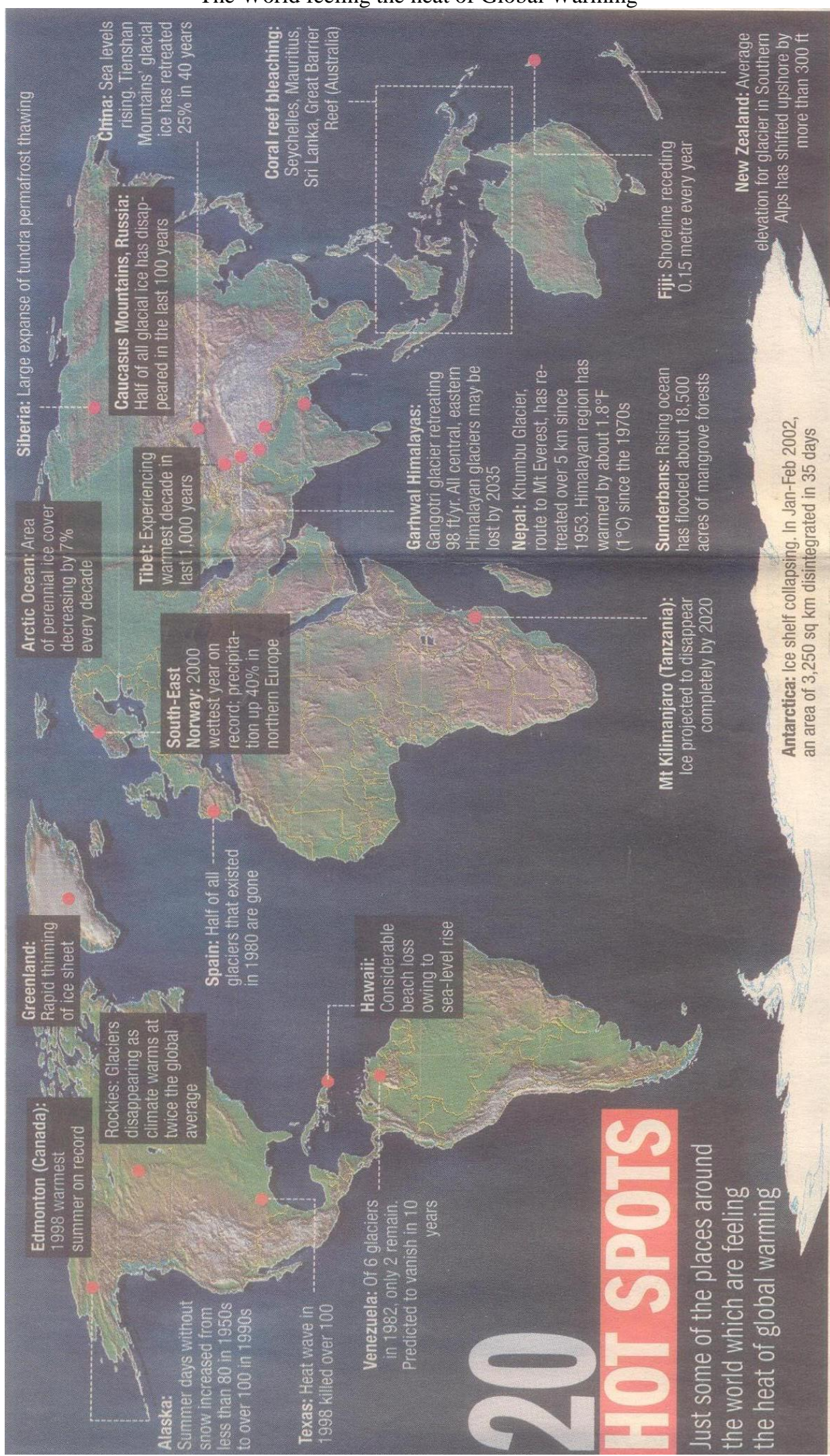

Source: The Times of India, 15 Jan 2006 